\title{
PENGARUH WAKTU REAKSI DAN RASIO MOL ASAM LINOLEAT DENGAN ISOPROPANOL PADA SINTESA PLASTISIZER ISOPROPIL LINOLEAT
}

\author{
Nirwana, Irdoni HS, dan Joni Miharyono \\ Jurusan Teknik Kimia Fakultas Teknik Universitas Riau \\ Email: nirwana.hamzah@yahoo.com
}

\begin{abstract}
Diversity of palm oil product in Indonesia is still limited, therefore it is needed to take an advantage of the development of downstream product of crude palm oil by esterification reaction. Esterification reaction is a reaction between carboxylic acid and alcohol to form ester. One of the emerging downstream product fatty acid alkyl ester is plasticizer. Plasticizer is an additive compound added to polymer to improve flexibility and workability. The purpose of this research was conducted to study the effect of reaction time and mole ratio and identify product of plasticizers isopropyl linoleic. In this research, plasticizer was synthesized by esterification of linoleic acid and isopropanol, using activated natural zeolite catalyst. The process was done with a variation of reaction time $(4,6$, and 8 hours) and mole ratio $(1: 6,1: 9$, and 1:12), with reaction temperature at $80{ }^{\circ} \mathrm{C}$, stirring speed at $200 \mathrm{rpm}$ and $15 \%$ of composition of linoleic acid based catalyst as fixed variables. From the analysis of the results showed that the esterification reaction time and mole ratio affect the product conversion. The best operating condition obtained in this research was 4 hours of reaction time and 1:12 of mole ratio which resulted the conversion of reaction was $67.09 \%$. Characteristics of plasticizer produced from this research were viscosity (at $20{ }^{\circ} \mathrm{C}$ ) 2.405 to $2.803 \mathrm{mPa}$.s and Specific Gravity (at $20{ }^{\circ} \mathrm{C}$ ) from 0.863 to 0.872 .
\end{abstract}

Keywords: Asam Linoleat, Esterifikasi, H-Zeolit, Isopropanol, Plastisizer

\section{PENDAHULUAN}

Perkembangan industri kelapa sawit di Indonesia khususnya provinsi Riau mengalami peningkatan cukup pesat. Hal ini dikarenakan Indonesia merupakan salah satu negara produsen kelapa sawit terbesar (No.2 di dunia setelah Malaysia) dengan jumlah produksi mencapai 23,9 juta ton [1]. Penggunaan minyak sawit mentah sebagai bahan baku minyak goreng dan margarin lebih kurang $45 \%$, sedangkan $55 \%$ lainnya merupakan bahan baku produk hilir seperti asam stearat, asam palmitat, asam miristat, plastisizer, surfaktan, biodiesel dan sebagainya ${ }^{[2]}$.

Pada umumnya pemanfaatan minyak sawit (CPO dan PKO) dapat di ubah menjadi produk hilir selanjutnya melalui reaksi esterifikasi. Reaksi esterifikasi minyak sawit menggunakan katalis asam telah banyak dilakukan untuk memperoleh fatty acid alkyl ester ${ }^{[3]}$. Produk hilir yang termasuk jenis fatty acid alkyl ester terdiri dari dua kategori yaitu produk pangan dan non-pangan. Produk pangan dapat berupa bahan pengelmusi dan margarin, sedangkan produk non-pangan (turunan) dapat berupa surfaktan, biodiesel dan plastisizer ${ }^{[2]}$.

Plastisizer secara konsep sederhana dapat diartikan sebagai pelarut organik, dapat berupa cairan dengan titik didih tinggi atau suatu padatan dengan titik leleh rendah ${ }^{[2]}$. Plastisizer adalah senyawa aditif yang ditambahkan kedalam polimer untuk meningkatkan fleksibilitas dan workabilitas ${ }^{[4]}$. Plastisizer komersil yang umum digunakan adalah plastisizer turunan minyak bumi yang non-biodegradable dan bersifat toxic, seperti Dioctyl Phthalate (DOP) atau Dietilheksil Phthalate (DEHP) dan Diiso Nonyl Pthalate (DINP) ${ }^{[5]}$. 
Komponen minyak kelapa sawit terdiri dari asam lemak yang berbeda-beda yaitu asam palmitat $44,3 \%$, asam oleat $38,7 \%$, asam linoleat $10,5 \%$, asam stearat $4,6 \%$, asam miristat $1 \%$, dan lainnya $0,9 \%{ }^{[2]}$. Berdasarkan komposisi asam lemak pada minyak sawit tersebut, dapat dikatakan bahwa asam palmitat, asam oleat, dan asam linoleat merupakan asam lemak yang terbesar dalam minyak sawit sehingga dapat dimanfaatkan menjadi produk hilir lebih bernilai. Asam linoleat hasil fraksinasi minyak sawit dapat dirubah menjadi fatty acid alkyl ester karena mempunyai struktur rantai karbon yang menyerupai minyak bumi. Asam linoleat juga merupakan bahan yang renewable dan ramah lingkungan ${ }^{[3]}$.

Reaksi esterifikasi untuk menghasilkan plastisizer membutuhkan katalis untuk mempercepat proses pembentukan produk. Katalis yang digunakan adalah katalis asam yang terdiri dari dua jenis yaitu katalis homogen dan katalis heterogen. Pada saat ini untuk menghasilkan plasitisizer komersil digunakan katalis homogen seperti asam sulfat $\left(\mathrm{H}_{2} \mathrm{SO}_{4}\right)$, asam nitrat $\left(\mathrm{HNO}_{3}\right)$ dan asam klorida $(\mathrm{HCl})$. Salah satu alternatif katalis yang dapat digunakan secara esterifikasi adalah katalis heterogen. Penggunaan katalis heterogen memiliki beberapa keuntungan yaitu mempermudah proses pemisahan antara hasil dan katalis ${ }^{[6]}$, dan memiliki keaktifan yang tinggi pada suhu rendah $\left(<100^{\circ} \mathrm{C}\right)^{[7]}$.

Salah satu katalis heterogen yang umum digunakan adalah zeolit alam. Zeolit alam yang diaktifasi menjadi H-Zeolit merupakan katalis asam yang mampu mengkatalisasi asam lemak dengan alkohol ${ }^{[8]}$. Dari uraian diatas, dipandang perlu untuk melakukan reaksi esterifikasi asam linoleat dan isopropil alkohol dengan menggunakan H-Zeolit.

\section{METODOLOGI PENELITIAN}

\section{Bahan dan Alat}

Bahan kimia yang digunakan dalam penelitian ini yaitu asam linoleat $\left(\mathrm{C}_{18} \mathrm{H}_{32} \mathrm{O}_{2}\right)$, zeolit alam, isopropanol $\left(\mathrm{C}_{3} \mathrm{H}_{8} \mathrm{O}\right)$, asam oksalat $\left(\mathrm{H}_{2} \mathrm{C}_{2} \mathrm{O}_{4}\right)$, aquades, indikator $\mathrm{pp}$ $\left(\mathrm{C}_{20} \mathrm{H}_{14} \mathrm{O}_{4}\right)$, ammonium klorida $\left(\mathrm{NH}_{4} \mathrm{Cl}\right) 1 \mathrm{~N}$, asam klorida $(\mathrm{HCl}) 6 \mathrm{~N}$, dan asam flour (HF) $3 \%$. Sedangkan alat yang digunakan terdiri dari: labu didih leher tiga, stirrer dan rotor, water bath, kondensor liebig, termometer, labu ukur, erlenmeyer, gelas ukur, gelas piala, corong pisah, pompa vakum, corong buchner, $\mathrm{pH}$ meter, oven, furnace, piknometer, buret, viscometer oswald, pipet tetes, batang pengaduk, neraca dan kertas saring. Berikut ini Gambar 1 adalah rangkaian alat reaktor untuk pembuatan plastisizer isopropil linoleat.

\section{Karakterisasi Zeolit Alam Diaktivasi}

Zeolit alam sebanyak $250 \mathrm{~g}$ digerus hingga mencapai ukuran 100 mesh. Zeolit alam yang sudah digerus di rendam dengan larutan asam flour 3\% selama 30 menit. Kemudian dicuci dengan aquades dan di keringkan dalam oven pada temperatur $105-110^{\circ} \mathrm{C}$ selama 3 jam. Zeolit di rendam dan di aduk kedalam larutan asam klorida $6 \mathrm{~N}$ selama 30 menit pada temperatur $50{ }^{\circ} \mathrm{C}$. Kemudian disaring dan di cuci dengan aquades berulang kali sampai pH 7, dikeringkan pada temperatur 105 $110^{\circ} \mathrm{C}$ selama 3 jam dalam oven.

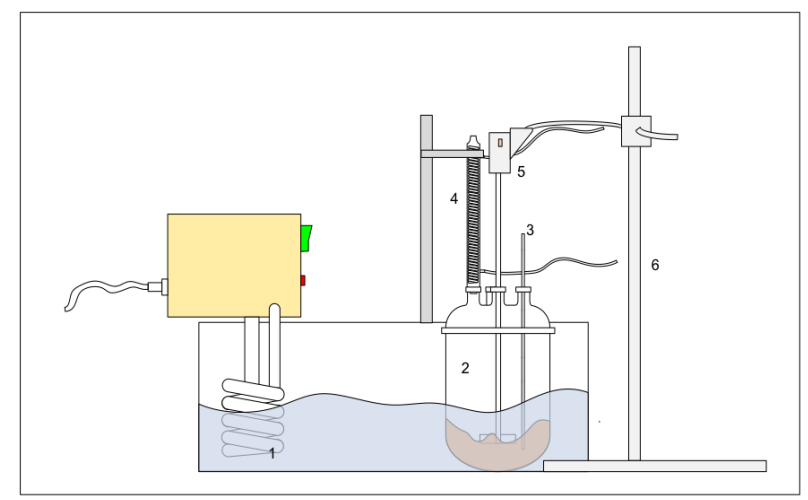

Keterangan :

1. Pemanas dan Water Bath

2. Reaktor

3. Termometer

4. Kondenser

5. Pengaduk

6. Statif

Gambar 1. Rangkaian reaktor untuk pembuatan isopropil linoleat. 
Zeolit alam di rendam dalam larutan ammonium klorida $1 \mathrm{~N}$ pada temperatur $90{ }^{\circ} \mathrm{C}$ selama 5 jam sambil diaduk didalam water bath. Lakukan penyaringan dengan kertas saring dan pompa vakum, cuci zeolit dengan aquades sampai fitltratnya mencapai $\mathrm{pH}$ 7. Setelah disaring, zeolit alam di keringkan pada suhu $105-110^{\circ} \mathrm{C}$ dengan oven selama 3 jam dan di kalsinasi dengan furnace pada suhu $500{ }^{\circ} \mathrm{C}$ selama 5 jam (gunanya untuk mengaktifasikan zeolit alam menjadi H-Zeolit) dan dilakukan analisa $X$ Ray Diffraction (XRD) untuk melihat mineral utama yang terkandung didalam H-Zeolit ${ }^{[9]}$.

\section{Sintesis Isopropil Linoleat}

Asam linoleat dimasukkan sebanyak $30 \mathrm{~g}$ ke dalam labu leher tiga yang dilengkapi pengaduk, selanjutnya dipanaskan sampai suhu $80{ }^{\circ} \mathrm{C}$ selama 15 menit di dalam labu leher tiga. Kemudian tambahkan katalis $\mathrm{H}$ Zeolit yang dikomposisikan $15 \%$ dari berat asam linoleat, selanjutnya tambahkan isopropanol yang divariasikan dengan perbandingan molar 1:6, 1:9, dan 1:12. Lakukan reaksi esterifikasi pada temperatur $80{ }^{\circ} \mathrm{C}$ dengan kecepatan pengadukan 200 rpm dan waktu reaksi yang telah di variasikan selama 4,6 , dan 8 jam. Hasil reaksi dimasukkan kedalam corong pisah dan didiamkan selama 24 jam, ambil lapisan ester dan dicuci dengan aquades dan dilakukan analisa GC-MS ${ }^{[2]}$.

\section{HASIL DAN DISKUSI}

\section{Karakteristik Zeolit Alam yang Diaktivasi}

Analisa X-Ray Diffraction (XRD) dilakukan untuk mengetahui jenis mineral yang terdapat pada katalis serta untuk mengetahui tingkat kristalinitas struktur komponen katalis, hal tersebut ditunjukkan oleh tinggi rendahnya intensitas puncak (20) pada difraktogram difraksi sinar X. Pola difraksi zeolit alam maupun $\mathrm{H}-Z$-Zolit dibandingkan nilai $2 \theta$ nya dengan data JCPDS No.6-239 (Joint Committee for Powder Diffraction Standars) ${ }^{[9]}$.

Zeolit alam yang berasal dari Bandung, Jawa Barat memiliki kandungan mineral utama berupa klinoptilolit dan mordenit. Mineralmineral ini terindentifikasi melalui pola difraktogram XRD.

Pada Gambar 2 terlihat adanya puncakpuncak mineral klinoptilolit dan mordenit pada zeolit alam. Puncak mineral klinoptilolit (K) terlihat pada $2 \theta 22,3400^{\circ} ; 26,6000^{\circ}$, dan $29,9600^{\circ}$. Sementara itu, puncak mineral mordenit (M) terlihat pada $2 \theta \quad 9,8400^{\circ}$; $13,4400^{\circ} ; 19,5800^{\circ} ; 25,6000^{\circ}$ dan $27,6400^{\circ}$. Hasil analisa XRD ini membuktikan bahwa zeolit alam yang digunakan mengandung mineral-mineral klinoptilolit dan mordenit dari zeolit.

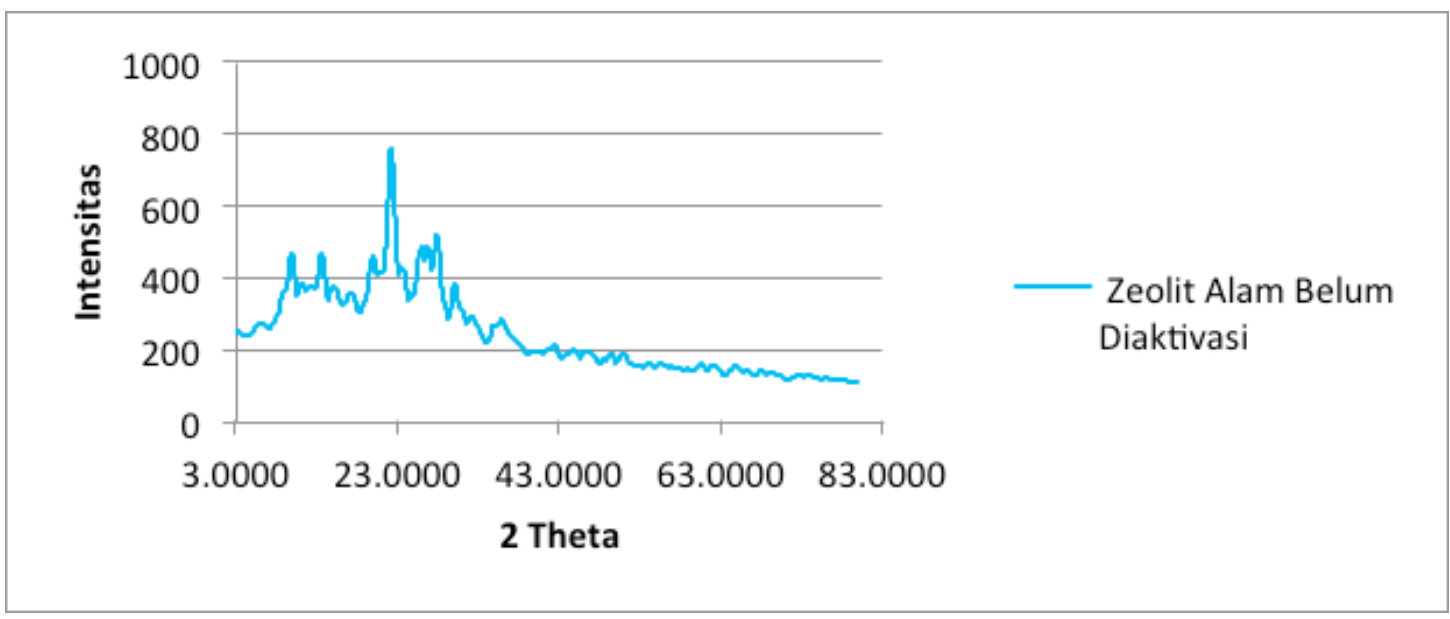

Gambar 2. Pola difraksi sinar X ZA belum diaktivasi. 
Pada Gambar 3 terlihat nilai intensitas puncak baik itu mordenit maupun klinoptilolit pada H-Zeolit dengan perendaman menggunakan asam flour 3\%, asam klorida $6 \mathrm{~N}$, dan ammonium klorida 1 $\mathrm{N}$ mengalami kenaikan 2-75 dibandingkan zeolit alam dan H-Zeolit tanpa menggunakan perendaman. Hal ini menunjukkan bahwa dengan melakukan modifikasi dan kalsinasi pada zeolit alam dengan perendaman menggunakan perlakuan perendaman dapat menyebabkan penurunan kandungan $\mathrm{Ca}, \mathrm{Fe}$, dan $\mathrm{Mg}$ pada zeolit alam dan meningkatkan keasaman zeolit sehingga kemampuan zeolit sebagai katalis semakin meningkat dengan menghasilkan luas permukaan yang lebih besar dan berpengaruh pada peningkatan volume total pori, sehingga dapat mempercepat proses pembentukan produk pada reaksi sintesa isopropil linoleat.

\section{Pengaruh Waktu Reaksi terhadap Konversi Reaksi Esterifikasi Isopropil Linoleat}

Pada proses sintesa isopropil linoleat, waktu reaksi memiliki peran penting untuk pembentukan produk selama proses berlangsung. Suatu reaksi akan berjalan sesuai dengan waktu, semakin lama waktu reaksi maka konversi akan bertambah sampai tercapainya kesetimbangan reaksi. Apabila kesetimbangan reaksi telah tercapai produk tidak akan bertambah lagi. Sesuai dengan prinsip Le Chatelier, pergeseran kesetimbangan reaksi dipengaruhi oleh suhu, perbedaan konsentrasi reaktan, volume reaktan, dan tekanan. Sedangkan penambahan katalis hanya mengakibatkan kesetimbangan reaksi cepat tercapai. Lama waktu reaksi tidak akan mempengaruhi pergeseran kesetimbangan reaksi, akan tetapi kita dapat mengetahui waktu tercapainya kesetimbangan reaksi.

Peneliti sebelumnya menyatakan bahwa setelah waktu reaksi mencapai kesetimbangan, konversi tidak akan bertambah lagi ${ }^{[10]}$. Hal yang sama juga dialami oleh Gunawan (2012) yang melakukan esterifikasi asam oleat dengan isobutanol menggunakan katalis H-Zeolit ${ }^{[1]}$. Hal yang sama juga terjadi pada penelitian ini, yang dapat dilihat pada Gambar 4. Dari grafik tersebut, didapatkan hasil bahwa dengan perbandingan mol 1:6 kesetimbangan reaksi tercapai pada waktu 4 jam dengan konversi 46,59\%, pada waktu 6 jam konversi reaksi tidak naik signifikan yaitu sebesar $47,72 \%$ karena telah terjadinya kesetimbangan reaksi pada waktu reaksi 4 jam.

Sedangkan pada perbandingan mol 1:9 dan $1: 12$, kesetimbangan reaksi juga tercapai pada waktu reaksi yang sama dengan konversi 50,10\% dan 67,09\%. Dari penelitian yang dilakukan didapatkan kondisi operasi yang baik pada waktu reaksi 4 jam.

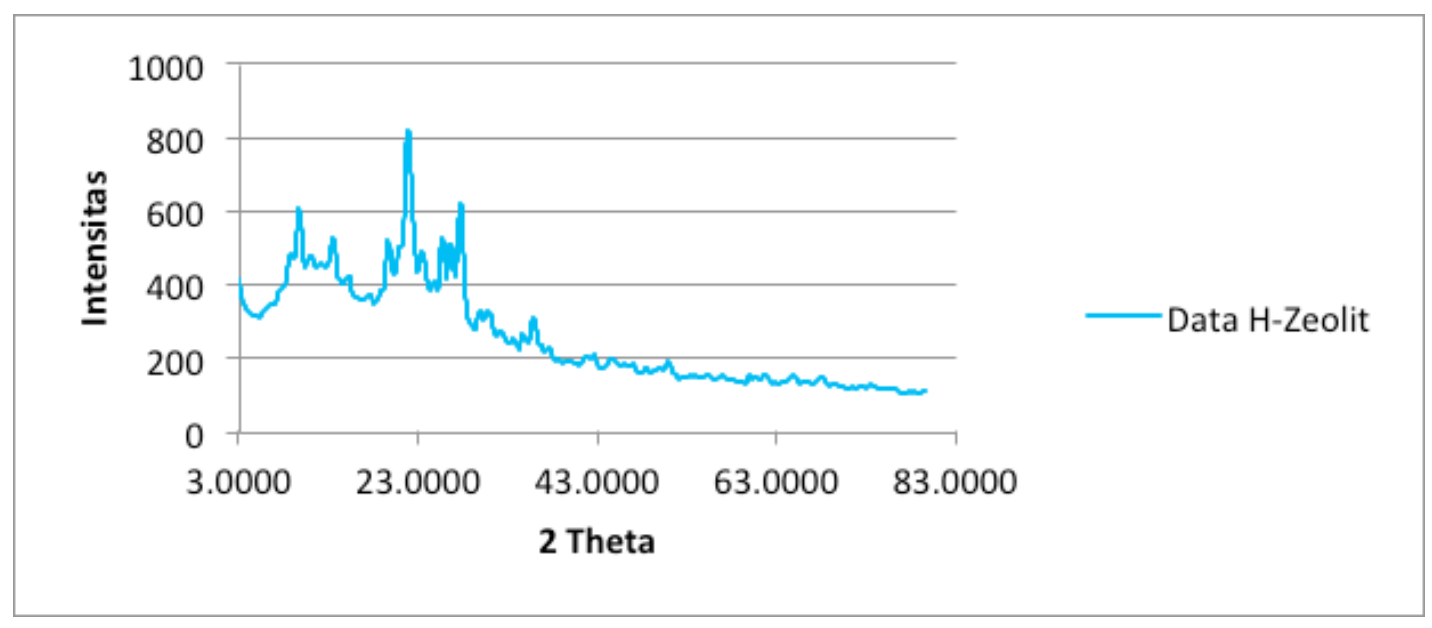

Gambar 3. Pola difraksi sinar X H-Zeolit. 


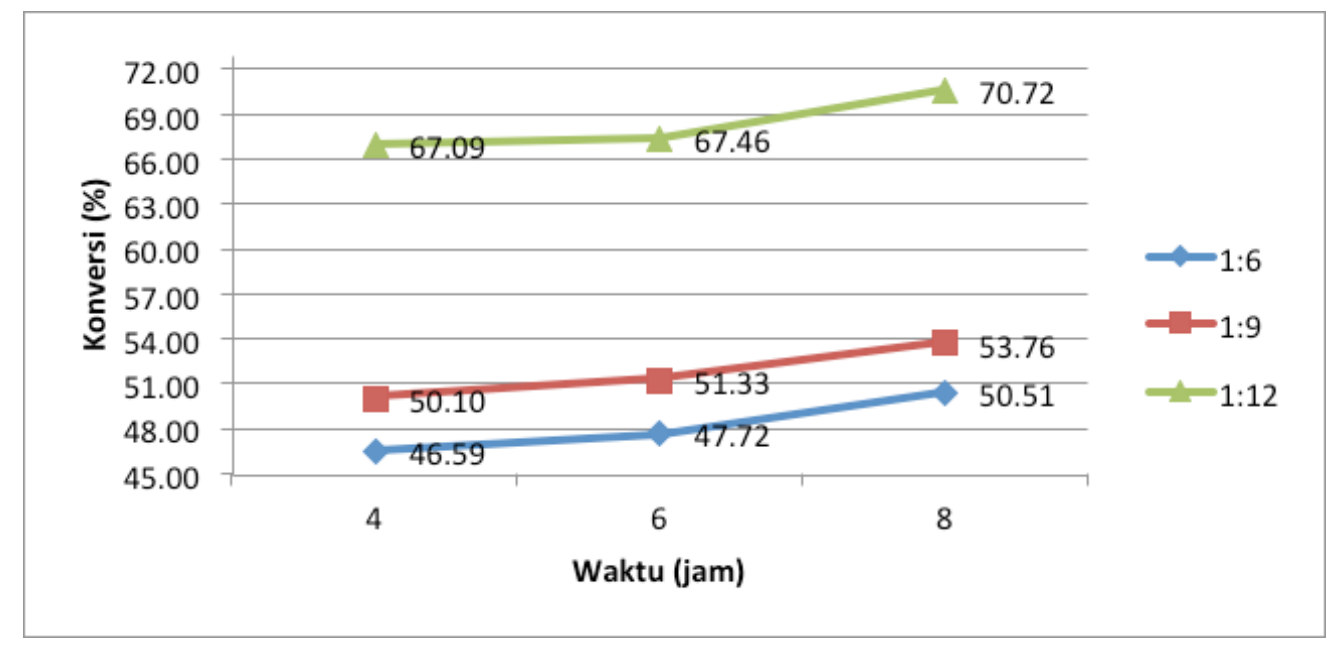

Gambar 4. Pengaruh waktu reaksi pembuatan isopropil linoleat.

\section{Pengaruh Perbandingan Mol terhadap Konversi Reaksi Esterifikasi Isopropil Linoleat}

Pada proses sintesa isopropil linoleat, perbandingan mol memiliki peran penting untuk pembentukan produk selama proses berlangsung. Perbandingan mol suatu reaktan akan menentukan konversi suatu produk yang dihasilkan. Hasil penelitian pengaruh waktu reaksi dan rasio mol pada sintesa plastisizer isopropil linoleat menunjukkan adanya pengaruh perbandingan mol terhadap konversi reaksi yang dapat dilihat pada Gambar 5.

Suatu reaksi akan berjalan sesuai dengan konsentrasi reaktan yang masih tersisa, semakin lama reaksi maka konsentrasi dari reaktan akan berkurang seiring dengan bertambahnya produk. Sesuai dengan prinsip Le Chatelier bahwa laju reaksi sebanding dengan konsentrasi reaktan. Perbandingan asam linoleat dan isopropanol 1:12 dapat menghasilkan konversi lebih tinggi dibandingkan dengan perbandingan rasio mol 1:6 dan 1:9. Tetapi untuk waktu reaksi 4 dan 6 jam, kenaikan konversi tidak signifikan. Pada waktu reaksi 4 jam, perbandingan rasio mol 1:12 menghasilkan konversi sebesar $67,09 \%$, perbandingan rasio $1: 9$ menghasilkan konversi sebesar 50,10\%, sedangkan perbandingan rasio 1:6 menghasilkan konversi sebesar 46,59\%.

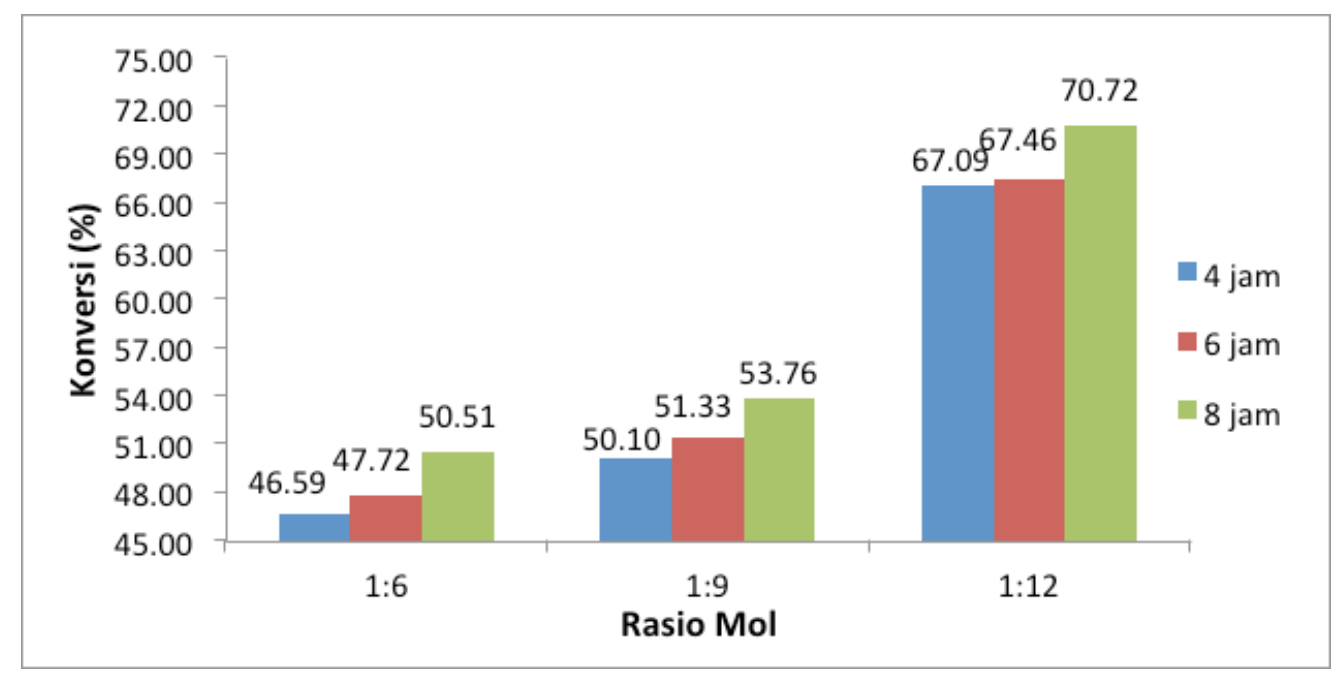

Gambar 5. Pengaruh perbandingan mol. 
Dari penelitian yang dilakukan didapatkan bahwa perbandingan asam linoleat dengan isopropanol 1:12 menghasilkan produk dengan konversi yang paling tinggi tetapi tidak terdapat perbedaan yang signifikan dengan perbandingan 1:6 dan 1:9. Hal ini dikarenakan reaksi sudah tercapai kesetimbangan, sehingga produk tidak akan terbentuk lagi. Apabila reaksi telah tercapai kesetimbangan, penambahan konsentrasi reaktan tidak akan berdampak pada hasil konversi ${ }^{[10]}$.

\section{Analisa GC-MS Produk}

Analisa dengan GC-MS dilakukan untuk mengetahui komponen yang terkandung didalam produk. Produk yang di analisa adalah hasil sintesa dengan rasio mol 1:12 waktu reaksi 4 jam dan kecepatan pengadukan $200 \mathrm{rpm}$ dapat dilihat pada
Gambar 6. Dari Gambar 6 menunjukkan puncak senyawa ester yang dihasilkan dari anlisa GC-MS dan puncak senyawa ester tersebut terlihat pada peak report table pada Gambar 7.

Gambar 7 menampilkan persentase ester dari asam linoleat dengan isopronal. Persen senyawa ester ini dapat dilihat pada puncak ke-3 dengan besar area 41,78\%. Hasil chromatogram dari puncak tersebut dapat dilihat pada Gambar 8

Berdasarkan Gambar 8 dengan Gambar 9 sebagai pembanding senyawa linoleic acid ethyl ester yang memiliki berat molekul 308 dapat disimpulkan bahwa gambar 8 merupakan senyawa linoleic acid isopropil ester dengan persen area $41,78 \%$ yang memiliki berat molekul 322.

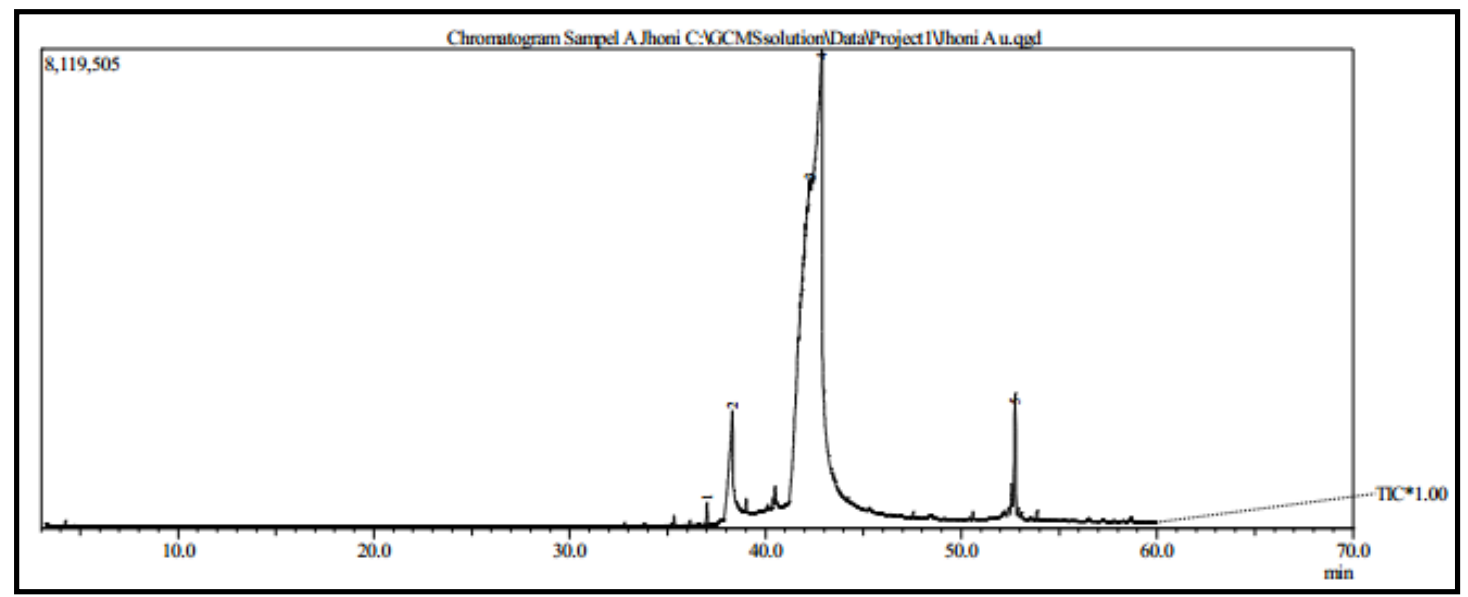

Gambar 6. Chromatogram produk sintesa isopropil linoleat dengan waktu reaksi 4 jam dan rasio mol 1:12.

\begin{tabular}{|rrrrrrr|}
\hline & & & & & \multicolumn{2}{c|}{ Peak Report TIC } \\
Peak\# & R.Time & I.Time & F.Time & Area & Area\% & Height Name \\
1 & 37.018 & 36.892 & 37.142 & 1419045 & 0.29 & 364202 \\
2 & 38.318 & 37.842 & 38.675 & 25684972 & 5.19 & 1694857 \\
3 & 42.275 & 41.158 & 42.342 & 206799071 & 41.78 & 5440049 \\
4 & 42.862 & 42.342 & 44.142 & 249643274 & 50.44 & 7517335 \\
5 & 52.765 & 52.408 & 53.008 & 11424744 & 2.31 & 1832417 \\
& & & & 494971106 & 100.00 & 16848860 \\
\hline
\end{tabular}

Gambar 7. Peak report GC-MS senyawa ester dari asam linoleat dengan isopropanol waktu reaksi 4 jam dan rasio mol 1:12. 


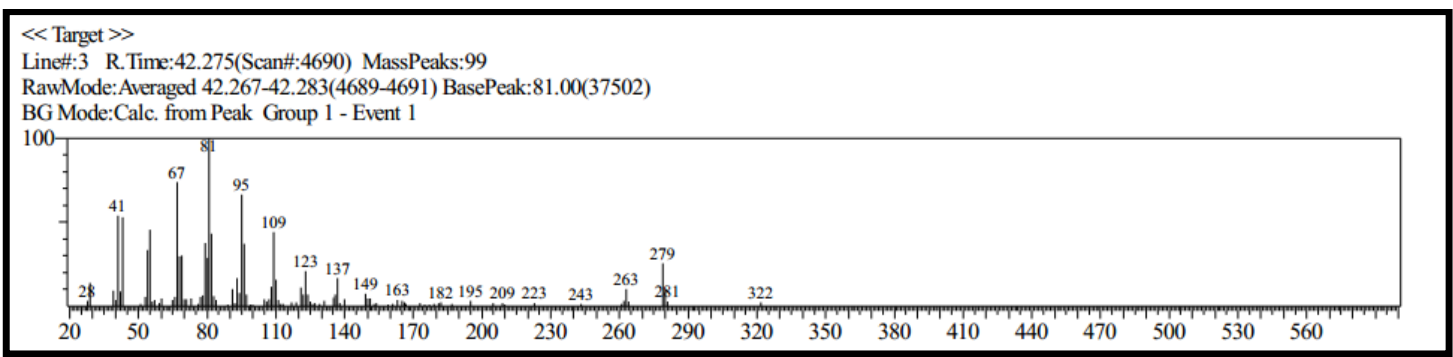

Gambar 8. Chromatogram senyawa hasil sintesis puncak ke-3.

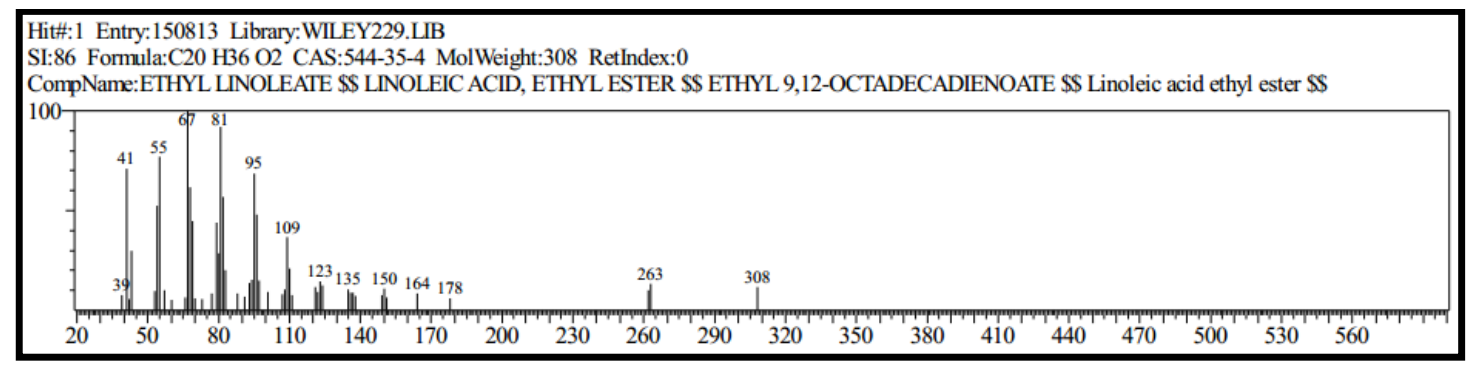

Gambar 9. Chromatogram senyawa linoleic acid ethyl ester.

Hasil analisis GC-MS menunjukkan bahwa persentase produk plastisizer yang dihasilkan adalah $41,78 \%$ adalah linoleic acid isopropil ester berbahan baku asam linoleat dengan isopropanol. Sedangkan 50,44\% merupakan linoleic acid yang belum teresterkan menjadi produk dikarenakan kemampuan katalis yang digunakan relatif masih kurang.

\section{Karakterisasi Produk Sintesa Isopropil Linoleat}

Karakteristik produk yang dihasilkan kemudian dibandingkan dengan karakterisik plastisizer komersil [Linolin Plastic Cosmetic. Inc.1950] dengan jenis asam linoleat. Tabel 1 adalah data karakteristik isopropil linoleat yang dihasilkan dari penelitian ini.

Tabel 1. Karakteristik produk dengan plastisizer komersil

\begin{tabular}{ccccc}
\hline & Waktu (jam) & $\begin{array}{c}\text { Specific Gravity } \\
\left(\mathbf{2 0}{ }^{\circ} \mathbf{C}\right)\end{array}$ & $\begin{array}{c}\text { Viskositas (20 } \\
(\mathbf{m P a} \mathbf{C})\end{array}$ & Konversi \\
\hline $\begin{array}{c}\text { Plastisizer } \\
\text { Komersil }\end{array}$ & - & $0,862-0,928$ & $8,2-9,4$ & - \\
\hline Produk & 4 & 0,863 & 2,524 & 46,59 \\
$(\mathbf{1 : 6 )}$ & 6 & 0,865 & 2,453 & 47,72 \\
& 8 & 0,872 & 2,455 & 50,51 \\
\hline Produk & 4 & 0,865 & 2,823 & 50,10 \\
$(\mathbf{1 : 9 )}$ & 6 & 0,866 & 2,439 & 51,33 \\
& 8 & 0,868 & 2,424 & 53,76 \\
\hline Produk & 4 & 0,866 & 2,454 & 67,09 \\
$(\mathbf{1 : 1 2})$ & 6 & 0,867 & 2,662 & 67,46 \\
& 8 & 0,869 & 2,405 & 70,72 \\
\hline
\end{tabular}


Dari Tabel 1 dapat dilihat bahwa untuk 9 sampel yang diuji specific gravity memiliki nilai yang sama dengan plasitisizer komersil jenis asam linoleat. Sedangkan untuk uji viskositas, 9 sampel yang diuji memiliki nilai yang berbeda dengan viskositas plastisizer komersil. Hal ini disebabkan bahwa penggunaan alkohol dalam pembuatan plastisizer jenis linoleat berbeda-beda, untuk yang sudah komersil menggunakan alkohol jenis butyl, butoxyethyl dan furfuryl ${ }^{[12]}$ dengan rantai karbon yang lebih panjang dibandingkan dengan isopropanol, sehingga karakteristik yang dihasilkan berbeda dengan isopropil linoleat.

Dapat dikatakan bahwa semakin panjang rantai karbon, maka nilai massa jenis akan semakin besar dan specific gravity akan semakin besar juga, hal ini juga berlaku pada viskositas. Dimana semakin panjang rantai karbon maka produk akan semakin kental sehingga nilai viskositas akan semakin besar.

\section{KESIMPULAN}

Pada penelitian ini waktu reaksi dan rasio mol pada sintesa plastisizer isopropil linoleat berpengaruh terhadap konversi, dan didapat kondisi operasi terbaik dengan waktu reaksi 4 jam, rasio mol 1:12, komposisi katalis 15\%, kecepatan pengadukan $200 \mathrm{rpm}$, dan suhu reaksi $80{ }^{\circ} \mathrm{C}$ dengan konversi sebesar $67,09 \%$. Karakteristik plastisizer isopropil linoleat yang dihasilkan yakni nilai viskositas $\left(20{ }^{\circ} \mathrm{C}\right)$ adalah $2,405-2,823 \mathrm{mPa} . \mathrm{s}$ dan specific gravity $\left(20^{\circ} \mathrm{C}\right)$ adalah $0,848-0,869$.

\section{DAFTAR PUSTAKA}

1. Rosalina. 2012. Perusahaan Sawit Terus Ekspansi Lahan. http://www.tempo.co/ read/news/2012/03/13/090390054/Perus ahaan-Sawit-Terus-Ekspansi-Lahan, 29/12/ 2013. Pkl 20.00 WIB.
2. Departemen Perindustrian Indonesia, Gambaran Sekilas Industri Minyak Kelapa Sawit. Jakarta (2010).

3. Handayani, A.S., Marsudi, S., Nasikin, M., Sudibandriyo, M., Reaksi esterifikasi asam oleat dan gliserol menggunakan katalis asam. Jurnal Sains Materi Indonesia. Edisi Oktober, 102105 (2006).

4. Haryono, A, Pengembangan Plastisizer Pengganti DOP dari Turunan Minyak Sawit. Bandung: Pusat Informasi dan Dokumentasi IPTEK LIPI, (2006).

5. Vieira, M.G.A, Mariana A.D.S, Licielen O.D.S ,. Natural based plasticizer and biopolymer films: A review, Eur. Polym. J. 47: 254-263 (2011).

6. Leach, B.E. Applied Industrial Catalysis. Volume 2. New York: Academic Press. Inc. (1983).

7. Hidesi, H., Heteregoneous basic catalysis. Chem. Rev. (95)3: 537-558 (1995).

8. Nasikin, M., Perengkahan katalitik fasa cair minyak sawit menjadi biogasolin. Prosiding Seminar Nasional Teknik Kimia Indonesia. Palembang 19-20 Juli. KKR 08-1, (2006).

9. Trisunaryanti, W., Triwahyuni, E., Preparasi modifikasi dan karakteristik katalis ni-mo/zeolit dan mo-ni/zeolit alam. TEKNOIN, (10)4: 269-282, (2005).

10. Susanto, B, Nasikin M, Sukirno. Sintesis pelumas dasar bio melalui esterifikasi asam oleat menggunakan katalis asam heteropoli/zeolit. Prosiding Seminar Nasional Rekayasa Kimia dan Proses. Semarang: Universitas Diponegoro, (2008).

11. Gunawan. Pengaruh waktu reaksi dan perbandingan molar pada proses pembuatan isobutil oleat dengan katalis zeolit alam. Skripsi. Pekanbaru: Universitas Riau (2012).

12. Wypych, G, Handbook of Plasticizer, Chemtech Publishing, Inc. (2004). 